\title{
ADOECIMENTO DAS PROFESSORAS DAS PRIMEIRAS LETRAS EM OLINDA: SINTOMAS, QUEIXAS E DIAGNÓSTICOS
}

\author{
EDNA MARIA RODRIGUES DE SOUZA ${ }^{*}$ \\ ORCID: https://orcid.org/0000-0002-0386-9823 \\ DIÓGENES JOSÉ GUSMÃO COUTINHO2** \\ ORCID: https://orcid.org/00000-0002-9230-3409
}

RESUMO:Análise das multicausalidades do fenômeno do mal-estare adoecimento das professoras das primeiras letras sob os aspectos físicos, psicológicos e sociais. A pesquisa foi feita a partir da perspectiva dos professores, considerando as possíveis consequências. Os resultados foram obtidos por meio de pesquisa qualiquantitativa com 32 professoras em três escolas municipais de Olinda - PE, Brasil. O objetivo principal foi descobrir e relacionar as principais queixas, sintomas e diagnósticos expostos em questionários semiestruturados. Descobrimos múltiplas causas, frequentes e recorrentes, provocadoras desse fenômeno, originando-se na prática docente e produzindo mal-estar. Entre estes, identificamos insônia, distúrbios da voz e da coluna, irritabilidade, fadiga física e mental, tensão, ansiedade e depressão. Observamos que políticas públicas, voltadas a essa classe trabalhadora responsável pelo alicerce da formação do sujeito, são urgentes e imprescindíveis.

Palavras chave: Professora. Mal-estar. adoecimento. Multicausadores.

\section{SUSCEPTIBILITY TO ILLNESS OF PRIMARY TEACHERS IN OLINDA: SYMPTOMS, COMPLAINTS} AND DIAGNOSES

ABSTRACT:Analysis of the multi-causality of the phenomenon of malaise and sickness of the teachers of the first letters under the physical, psychological and social aspects. The research was done from the perspective of the teachers, considering the possible consequences. The results were obtained through qualitative research with 32 teachers in three municipal schools in Olinda PE, Brazil. The main objective was to discover and relate the main complaints,

${ }^{1}$ Prefeitura da Cidade de Olinda, Recife, PE, Brasil.

${ }^{2}$ Faculdade ALPHA, Recife, PE, Brasil.

"Professora da Prefeitura da Cidade de Olinda, Analista de Gestão Educacional do Estado de Pernambuco, Pedagoga, Especialista em Recursos Humanos em Educação, Mestre em Ciências da Educação, Doutoranda em Ciências da Educação-Educação e Saúde-Atenas College University/ PPG/ Faculdade ALPHA, RecifePE-Brasil. E-mail:<mariadaserra@gmail.com>.

"* Biólogo, Mestre em Biologia, Doutor em Biologia, Professor do PPG/Faculdade ALPHA e do Centro Universitário Brasileiro - UNIBRA, Recife-PE-Brasil. E-mail:<gusmao.diogenes@gmail.com>. 
symptoms and diagnoses exposed in semi-structured questionnaires. We discovered multiple causes, frequent and recurrent, that provoked this phenomenon, originating in the teaching practice and producing malaise. Among these, we identified insomnia, voice and spine disorders, irritability, physical and mental fatigue, tension, anxiety, and depression. We observe that public policies, directed to this working class responsible for the foundation of the formation of the subject, are urgent and indispensable.

Keywords: Teacher. Malaise. Multiple Factors causing Illness.

\section{INTRODUĈ̣̃O}

Diante da elevada e progressiva deteriorização da saúde mental, física e social no qual o sujeito professor se encontra, dentro e fora do ambiente de trabalho, objetivamos conhecer, elencar e analisar o fenômeno do mal-estar docente a partir da compreensão de como se dava o adoecimento em 32 professoras da educação infantil e anos iniciais do Ensino Fundamental, em três Unidades de Ensino (UE), de porte médio e com estruturas físicas e humanas semelhantes, na rede municipal de Olinda-PE. Para tanto, sublinhamos os contributos e condicionantes, visualizando os aspectos físicos, psicológicos e sociais no cenário da prática docente.

Neste contexto de sofrimento e mal-estar do professor, encontramos estudiosos como Esteve Zaragoza (1984, 1994, 1995, 1999), Maslach e Leiter, (1999, apud CARLOTTO, 2002, p.23), e na atualidade, Andrade e Cardoso (2016), Baião e Cunha (2013), Borba et al. (2015), entre tantos. As condições estruturais das UEs desenham mal-estar alardeado em eco pelas professoras, colocando em discussão a relação com a saúde e o adoecimento, traduzido em licenças, afastamentos do trabalho e interferências em seu labor e em sua vida afetiva, física, emocional e social. Identificamos na literatura, a relação fundamentadora desta inquietação entre o mal-estar e adoecimento docente (FREUD; 1924; DALAGASPERINA; MONTEIRO, 2014; REIS, 2014; OZOILO, 2015; DIEHL; MARIN, 2016).

Em seu estudo nos anos de 2007 a 2012, Camargo (2014) detectou que algumas doenças se revezavam entre os causadores de afastamento de alguns setores entre estes, da educação. Dentre essas, lesões dos membros e do pescoço, alguns traumatismos osteomusculares (LER/DORT) e transtornos e distúrbios mentais. Observou também que o CID 10 (Classificação Internacional de Doenças), referente aos transtornos mentais como um dos responsáveis pela incapacitação do profissional da educação. Nos resultados obtidos em nosso trabalho, enxergamos que as condições 
precárias de algumas UE (Unidade de Ensino), a visão da sociedade acerca do professor, a histórica desvalorização financeira e social da função, contribui com significativa porção de culpa, refletida negativamente no sujeito professor.

Neste sentido a Organização Internacional do Trabalho (OIT) considera a atividade docente como uma das mais estressantes e desgastantes e geram repercussões na saúde física, psicológica e profissional (BORGES DOS REIS et al., 2006).

Diante do exposto, surgiram as hipóteses elencadas no referente à influência do estilo de vida dos docentes com as doenças relatadas por eles; no adoecimento na categoria docente decorrente dos elevados níveis de estresse pelos quais passam e nos quais estão envolvidos. As condições de trabalho (salários, deslocamentos, carga horária excessiva, salas superlotadas, trabalho em pé, uso demasiado da voz, dentre outros), têm levado o profissional professor ao esgotamento físico e, portanto, ao adoecimento do corpo e da mente. A indisciplina dos alunos e a falta de acompanhamento dos pais estão entre os principais fatores causadores da irritabilidade, insônia, cansaço mental, estados de depressão e ansiedade que acometem os profissionais destes seguimentos de ensino. Fatores sociais e da comunidade escolar (governo negligente, ausência de políticas públicas, gestão, coordenação, alunos, professores, pais), relação conjugal, familiar e social dos professores são decisivos para o surgimento de problemas de saúde.

Assim, nos fundamentamos nos trabalhos decorrentes da epidemiologia para a concepção da teoria da multicausalidade para compreendermos os diversos fatores que permeiam este fenômeno (AROUCA, 1976; BARATA, 1998; MACMAHON et al., 1965; PENNA, 2006). Justificando-se esse estudo pela necessidade de se conhecer mais profundamente os condicionantes relativos às condições de trabalho e a saúde dos docentes.

Várias são as queixas das professoras relatadas na tabela 4 merecendo em quase sua totalidade uma especial atenção tendo em vista a quantidade das que afirmam sentir pelos menos quatro ou cinco entre as variáveis disponíveis, como relacionamos a seguir as mais apontadas: cansaço, 93,8\%; dificuldade em levantar-se pela manhã, 87,5\%; noites mal dormidas, 59,4\%; ansiedade, 37,5\% (TABELA 4).

É importante que trabalhos desse enfoque sejam feitos para que o fenômeno do adoecimento do professor seja mais bem compreendido sobre diversas óticas (física, mental e social), além da sugestão de traçar estratégias de cunho prático para esse problema tão atual e recorrente. Pretendemos ainda, com o estudo social da condição do professor, evidenciar um aspecto pouco estudado e 
conhecido pela ciência, que seria a relação entre as condições sociais (entende-se aqui por social, não só questões financeiras, também, as relações familiares) do professor e seu fazer docente.

\section{PERCURSO METODOLÓGICO}

O presente trabalho parte da pesquisa de natureza aplicada e exploratória, tendo em vista a procura por características de um grupo determinado, abordando qualitativamente os resultados. Porém, devido à necessidade de quantificar em linguagem matemática e estatística, fizemos um aporte quantitativo. Bebendo da concepção de Dejours (apud LANCMAN, SZNELMAN (org.), 2004) buscamos a fundamentação sociofilosófica da Psicodinâmica do Trabalho. Quanto aos fins, consideramos nossa construção descritiva, partilhando da afirmação de Gil (2010, p. 27) quando alega que nesta pesquisa "[...] têm como objetivo a descrição das características de determinada população".

Ainda neste sentido, Vergara (2005, p. 47) cita que embora não se proponha a explicar os acontecimentos que descreve, essa pesquisa poderá contribuir para que esta explicação ocorra. Portanto, objetivamos elencar, pontuar, analisar e explicar o mal-estar e os desconfortos pelos quais os professores são acometidos. Dessa forma, a escolha por uma pesquisa descritiva explicativa se faz justificar. Corroboramos com Minayo $(2001,2008)$ acerca da pesquisa qualitativa, quando relata que existe a preocupação de compreender a fundo as particularidades de um grupo inserido em uma organização social determinada. Neste caso, em que a pesquisa está focada em acontecimentos sociais de um grupo determinado, a partir da visão dos envolvidos nestas relações sociais, Minayo $(2008,2001)$ assegura que a abordagem qualitativa é mais propícia. Pois, aqui, o experimental e o ordenamento progressivo acerca do que se objetiva conhecer estão envolvidos. Assim como o entendimento da logicidade do grupo em foco. Ainda são passíveis de estatísticas e, portanto, deverão ser quantificados para uma explicação matemática. Para tanto, buscamos nos procedimentos metodológicos perseguidos, a base para alcançar o objetivo geral e descrever os fatos e fenômenos, coletando dados através de questionários semiestruturados.

Assim, construímos uma pesquisa de campo, descritiva e quali/quantitativa. Objetivamos identificar e elencar as multicausas e possíveis responsáveis pela ocorrência do fenômeno observado. Neste sentido, parafraseamos Gil (2010, p. 27, 28), quando diz que estas pesquisas "podem ser elaboradas também com a finalidade de identificar possíveis relações entre variáveis". 
A pesquisa foi realizada em três escolas da rede municipal da cidade de Olinda em Pernambuco. Utilizamos como critério de escolha o fato de serem estas as que mais apresentaram afastamento de professores por motivo de doenças no período de 2010 a 2015. Neste cenário, buscamos identificar as características desse grupo, alinhando por idade, gênero, tempo de serviço, segmento de ensino, estado de saúde, dentre outras. Essas Unidades de Ensino, dentro dos parâmetros da rede municipal de Olinda, são consideradas de grande porte. Possuem 12 salas em média, em torno de 700 estudantes cada uma e funcionam nos turnos da manhã, tarde e noite, oferecendo os segmentos de ensino desde a Educação Infantil, Ensino Fundamental e Educação de Jovens e Adultos Fundamental.

A amostragem dos professores para a pesquisa se deu através de um critério seguindo as seguintes características: professor readaptado da função docente definitivamente, professor afastado temporariamente e que retornou à função em sala de aula, os que apenas já se afastaram da docência com licença médica e outros docentes que nunca se afastaram, entre os anos de 2010 e 2015. E claro, levando em conta a disponibilidade e disposição desses profissionais para responder ao questionário.

Para obtenção dos resultados, tentamos analisar aspectos da saúde física, emocional e psicológica que acomete os profissionais dos segmentos de ensino escolhidos, utilizamos o instrumento de coleta chamado de questionário semiestruturado, com qual foi possível conhecer detalhes pessoais e profissionais do docente, a partir da adaptação de TALIS - INEP, Reis e Maués (2007) e Bastos (2009). Para tanto, buscamos os profissionais no Encontro Pedagógico de abertura do ano letivo de 2016, onde os docentes estavam em grande número determinados à pesquisa com a disponibilidade de tempo para respondêlo. Outras situações e momentos, como por exemplo, o horário do recreio, o momento no ônibus para deslocamentos de uma escola a outra, horário do almoço, buscando sempre respeitar os momentos propícios a cada protagonista. Esse procedimento fora realizado garantindo o sigilo absoluto e preservando a identidade das Unidades de Ensino e dos atores envolvidos. Portanto, no decorrer da construção desse trabalho e em todos os questionários, as escolas e os profissionais em questão, foram identificadas por um código previamente estabelecido.

No tocante a questões éticas, as abordagens e instrumentos metodológicos obedeceram aos procedimentos éticos estabelecidos para pesquisa científica em ciências humanas. 


\section{RESULTADOS E DISCUSSÃO}

\section{ANÁLISE DOS DADOS SOCIODEMOGRÁFICOS E DAS CONDIC̣ÕES DE TRABALHO}

Encontramos profissionais com uma média de idade de 45 anos e com especialização concluída e $12,5 \%$ mestres. $O$ vínculo empregatício com a Prefeitura de Olinda é de 87,5\% efetivo, ou seja, são concursados e 100,0\% sexo feminino (TABELA 1).

Acerca da predominância de mulheres na educação a redação do Todos pela Educação revela que oito em cada dez professores na educação básica são mulheres. Constatando que as mulheres ocupam 81,5\% do total de professores neste segmento no Brasil (HARNIK, 2011). No entanto, não se restringe só a Educação Básica, no portal do INEP, na página das Sinopses Estatísticas da Educação Básica, em 2014, é apontado que entre os professores brasileiros, 1.753 .870 são mulheres, enquanto 436.873 são homens. Afirmando que esse total de professoras representa em torno de $3 / 4$.

Outro fator determinante para decidirmos por esta amostragem referiu-se ao tempo de docência dessas profissionais na rede municipal de Olinda onde apenas 25\% têm menos de 10 anos como professoras, no entanto, a maioria representando $46,9 \%$ das questionadas já leciona há até 20 anos e 18,8\% até 30. Um dado relevante é que 50\% desta amostra estão na mesma escola há pelo menos 15 anos e 40,6\% há 20, o que determina conhecimento profundo da realidade física e estrutural assim como acerca dos relacionamentos sociais entre a comunidade e a unidade (TABELA 1).

Entre estes achados observamos uma prevalência significativa na indicação da carga horária extensa e exaustiva onde $90,63 \%$ das professoras têm de 30 a 40 horas semanais de atividades (TABELA 1), muitas vezes duplas, algumas triplas, como um dos fatores que predominam entre os causadores de sofrimento e adoecimento físico, psicológico e social no docente, chegando às vezes ao afastamento da prática pedagógica.

Nesse seguimento, encontramos na literatura, autores como Baião e Cunha (2013), Cardoso e Costa (2016), Pizzio e Klein (2015), Reis (2014) entre outros, que indicam a questão da carga horária elevada, a longa jornada de trabalho, o excesso de trabalho em atividades administrativas, burocráticas e de assistência, como o fator determinante para o adoecimento do docente. Os autores reforçam que a maioria dos seus entrevistados relatou trabalhar mais de 40 horas semanais em mais de uma instituição, alguns deles em três, e realizam atividades que vão além da sala de aula e da escola. 
TABELA 1. Caracterização dos aspectos sociodemográficos dos professores

\begin{tabular}{|c|c|c|c|}
\hline VARIÁVEIS & & $\begin{array}{r}\mathbf{N}^{0} \text { de } \\
\text { professoras }\end{array}$ & $\%$ \\
\hline \multirow{3}{*}{ Idade } & De 30 a 40 & 6 & 18,5 \\
\hline & De 40 a 50 & 21 & 65,6 \\
\hline & De 50 a 60 & 5 & 15,6 \\
\hline \multirow{4}{*}{ Escolaridade } & Graduação & 0 & 0,0 \\
\hline & Especialização & 28 & 87,5 \\
\hline & Mestrado & 4 & 12,5 \\
\hline & Outros & 0 & 0,0 \\
\hline \multirow{2}{*}{ Reside em Olinda } & Sim & 4 & 12,5 \\
\hline & Não & 28 & 87,5 \\
\hline \multirow{3}{*}{$\begin{array}{l}\text { Deslocamento casa/ } \\
\text { trabalho/casa }\end{array}$} & Ônibus & 21 & 65,6 \\
\hline & Carro & 9 & 28,1 \\
\hline & A pé & 2 & 6,0 \\
\hline \multirow{3}{*}{$\begin{array}{l}\text { Quantidade de transportes no } \\
\text { deslocamento de casa? trabalho }\end{array}$} & Até 2 & 8 & 25,0 \\
\hline & Até 3 & 22 & 68,8 \\
\hline & Mais de 3 & 2 & 6,0 \\
\hline \multirow{2}{*}{ Tem companheiro } & Sim & 29 & 91,0 \\
\hline & Não & 3 & 9,0 \\
\hline \multirow{3}{*}{ Filhos } & Até 1 & 21 & 65,6 \\
\hline & Até 2 & 7 & 22,8 \\
\hline & Sem filhos & 4 & 12,6 \\
\hline \multirow{4}{*}{ Tempo de docência } & Até 10 anos & 8 & 25,0 \\
\hline & Até 20 anos & 15 & 46,9 \\
\hline & Até 30 anos & 6 & 18,8 \\
\hline & Mais de 30 anos & 3 & 9,4 \\
\hline \multirow{3}{*}{$\begin{array}{l}\text { Tempo de docência na } \\
\text { Unidade de Ensino }\end{array}$} & Até 15 anos & 16 & 50,0 \\
\hline & Até 20 anos & 13 & 40,6 \\
\hline & Mais de 20 anos & 3 & 9,4 \\
\hline \multirow{2}{*}{$\begin{array}{l}\text { Jornada de trabalho semanal na } \\
\text { Unidade de Ensino em horas }\end{array}$} & Até 30hs & 3 & 9,4 \\
\hline & De 30 a 40 & 29 & 90,7 \\
\hline \multirow{3}{*}{$\begin{array}{l}\text { Níveis de Ensino em } \\
\text { que trabalha }\end{array}$} & Ed. Infantil & 5 & 15,6 \\
\hline & $\begin{array}{r}\text { Anos iniciais do Ensino } \\
\text { fundamental }\end{array}$ & 22 & 68,8 \\
\hline & Os dois & 5 & 15,6 \\
\hline
\end{tabular}




\begin{tabular}{|c|c|c|c|}
\hline $\begin{array}{l}\text { Vínculo trabalhista } \\
\text { com Olinda }\end{array}$ & $\begin{array}{r}\text { Efetivo } \\
\text { Contrato } \\
\text { outro }\end{array}$ & $\begin{array}{r}28 \\
3 \\
1\end{array}$ & $\begin{array}{r}87,5 \\
9,4 \\
3,0\end{array}$ \\
\hline $\begin{array}{l}\text { Quantidade de vínculos } \\
\text { que possui }\end{array}$ & $\begin{array}{r}\text { Um } \\
\text { Dois } \\
\text { Mais de dois }\end{array}$ & $\begin{array}{r}3 \\
26 \\
3\end{array}$ & $\begin{array}{r}9,4 \\
81,3 \\
9,4\end{array}$ \\
\hline $\begin{array}{l}\text { Outra atividade } \\
\text { remunerada }\end{array}$ & $\begin{array}{l}\text { Sim } \\
\text { Não }\end{array}$ & $\begin{array}{r}3 \\
29\end{array}$ & $\begin{array}{r}9,4 \\
90,6\end{array}$ \\
\hline $\begin{array}{l}\text { Jornada de trabalho } \\
\text { semanal em horas }\end{array}$ & $\begin{array}{r}\text { Até } 30 \\
\text { De } 30 \text { a } 40 \\
\text { Mais de } 40\end{array}$ & $\begin{array}{r}3 \\
26 \\
3\end{array}$ & $\begin{array}{r}9,4 \\
81,3 \\
9,34\end{array}$ \\
\hline $\begin{array}{l}\text { Renda familiar em } \\
\text { salários mínimos }\end{array}$ & $\begin{array}{r}\text { Menos de } 3 \\
\text { Até } 3 \\
\text { De } 3 \text { a } 5 \\
\text { Mais de } 5\end{array}$ & $\begin{array}{r}2 \\
3 \\
24 \\
3\end{array}$ & $\begin{array}{r}6,3 \\
9,4 \\
75,0 \\
9,4\end{array}$ \\
\hline
\end{tabular}

Fonte: dados da pesquisa.

A tabela 1 demonstra um resultado revelador de que em nossa pesquisa não foi diferente e corrobora com Reis (2014) que constatou em seu estudo, que a longa jornada de trabalho e a quantidade de atribuições que os professores têm, inclusive fora da sala de aula e da escola, serem fatores desencadeantes de mal-estar, sofrimento e adoecimento físico, psicológico e por consequência social.

Entre as professoras questionadas no nosso trabalho, a grande maioria reforça a necessidade de trabalhar em mais de um vínculo, às vezes até três, para suprir as necessidades básicas do dia a dia das famílias. Encontramos entre elas, apenas 9,4\% com trabalho em um só horário. No entanto, as dificuldades e privações são relatadas. Enquanto que $81,25 \%$ trabalham até 40 horas semanais em duas redes e 9,38\% mais de 40 horas por semana como professora, distribuídas em três turnos.

Outra questão agravante para o adoecimento do professor, conjugada a esta necessidade de cumprir jornadas extensivas, se refere aos deslocamentos diários, quando 65,5\% das professoras utilizam os transportes públicos precários, superlotados, escassos e desconfortáveis do nosso estado. Pois detectamos que $87,5 \%$ não residem em Olinda. E, ainda, como mostra a tabela 2, 68,8\% utilizam até três coletivos diariamente, no deslocamento de casa para o trabalho. Percebemos também que $87,5 \%$ ultrapassam fronteiras municipais, alguns até duas, todos os dias. Toda essa luta intensa se deve aos baixos salários que são oferecidos aos professores. 
Acerca desse sentimento de exaustão física, mental e emocional nos docentes, Silva e Guillo (2015) constataram que ocorre quando associado aos obstáculos diários. Essa exaustão diária, o estresse recorrente e o acometimento da Síndrome de Burnout, são detectados por Vale e Aguillera (2016) como sendo as principais causas dos afastamentos esses profissionais.

\section{ANÁLISE DOS ASPECTOS PEDAGÓGICOS E DA FORMAC̣ÃO DOS PROFESSORES}

Contextualizando, na tabela 2 está exposto que 6,0\% revelou ter até 25 alunos por sala, predominantemente na Educação Infantil. No entanto, 28,0\% afirmaram ter até 30 estudantes em sua sala, no $1^{\circ}$ e $2^{\circ}$ anos, $41,0 \%$ das professoras do $3^{\circ}$ e $4^{\circ}$ anos, declaram que chegam até 40 crianças para trabalharem todos os dias e $25 \%$ docentes do $5^{\circ}$ ano afirmam ter mais de 40 estudantes em sua turma. As profissionais alegam as dificuldades que enfrentam e reiteram ser impraticável essa quantidade de estudantes numa mesma sala.

É importante salientar que em 25 de outubro de 2016, o Secretário de Educação do município de Olinda publica com o aval do conselho municipal de educação uma Emenda à Portaria de 22 de setembro de 2015 estabelecendo normativas, entre estas a que indica o limite de alunos por sala em cada segmento de ensino oferecido pela rede. Para Educação Infantil, a norma define a quantidade de oito até dez alunos nos Grupos I e II (crianças de zero até um ano e a partir de um ano, respectivamente); de doze até 15 nos Grupos II e IV (crianças a partir de dois e três anos, respectivamente); de 18 até 20 nos Grupos $\mathrm{V}$ e VI (crianças a partir de quatro e cinco anos, respectivamente).

Observamos entre as professoras dessa construção, que apenas $9,4 \%$ contam com mais de cinco salários mínimos mensais de renda familiar. Em contrapartida, 6,3\% que sobrevivem com até três salários por mês e $75,0 \%$ com uma receita entre três e cinco para toda a família. Neste contexto Dias (2014) apurou pesquisando 352 professores, que a maioria indicou insatisfação com o salário que recebe. Enfatizando a precarização do ensino como um fator indicativo de desvalorização com a educação. Neste sentido, Leonardo e Suzuki (2016) opinam ter sido este um dos fatores preponderantes para o adoecimento do docente.

A profissão professor agrega necessidades que denotam despesas. A formação continuada é uma delas, pois, corresponde a uma contínua construção, aperfeiçoamento e enriquecimento de conhecimentos que visam a práticas pedagógicas coerentes com as mudanças sociais, culturais, com a globalização de uma maneira 
ampla. Foi-nos possível perceber que 90,38\% das professoras desta pesquisa, demonstram a necessidade de participar de mais formações além das oferecidas anualmente pela Secretaria de Educação do município (TABELA 2). Lira e Medeiros (2015) afirmam que os professores se sentem despreparados diante das novas dinâmicas e conflitos a que são expostos.

No entanto paira sobre este grupo a dificuldade de custear cursos com recursos próprios, pois observamos que quase $10 \%$ das professoras protagonistas neste trabalho exercem outra atividade remunerada além da docência para conseguir suprir e manter as necessidades básicas da família, como mostra a tabela 1. Neste sentido, a CNTE (Confederação Nacional dos Trabalhadores em Educação) afirma que o piso salarial dos professores em 2017 deverá ser de R 2.298,80.

TABELA 2. Caracterização dos aspectos pedagógicos.

\begin{tabular}{|c|c|c|c|}
\hline VARIÁVEIS & & $\begin{array}{r}\mathbf{N}^{0} \text { de } \\
\text { professoras }\end{array}$ & $\%$ \\
\hline \multirow{2}{*}{$\begin{array}{l}\text { Formação Continuada } \\
\text { na rede de Olinda }\end{array}$} & Sim & 32 & 100,0 \\
\hline & Não & 0 & 0,0 \\
\hline \multirow{4}{*}{$\begin{array}{l}\text { Quantidade de Formação } \\
\text { Continuada na rede de } \\
\text { Olinda }\end{array}$} & Nenhuma por ano & 0 & 0,0 \\
\hline & 1 por ano & 3 & 9,4 \\
\hline & 2 por ano & 8 & 25,0 \\
\hline & Mais de 2 por ano & 21 & 65,6 \\
\hline \multirow{3}{*}{$\begin{array}{l}\text { Impacto na prática } \\
\text { pedagógica } \\
\text { da formação em rede }\end{array}$} & Grande impacto & 21 & 65,6 \\
\hline & Pequeno Impacto & 9 & 28,0 \\
\hline & Nenhum Impacto & 2 & 6,0 \\
\hline \multirow{2}{*}{$\begin{array}{l}\text { Necessidade de } \\
\text { maisFormação }\end{array}$} & Sim & 29 & 90,4 \\
\hline & Não & 3 & 9,4 \\
\hline \multirow{2}{*}{$\begin{array}{l}\text { Formação com } \\
\text { recursos próprios }\end{array}$} & Sim & 4 & 12,5 \\
\hline & Não & 28 & 87,5 \\
\hline \multirow{3}{*}{$\begin{array}{l}\text { Impacto na prática } \\
\text { pedagógica da formação } \\
\text { com recursos próprios }\end{array}$} & Grande impacto & 21 & 65,6 \\
\hline & Pequeno Impacto & 3 & 9,4 \\
\hline & Nenhum Impacto & 0 & 0,0 \\
\hline \multirow{4}{*}{$\begin{array}{l}\text { Quantidade de estudantes } \\
\text { em sua sala de aula }\end{array}$} & Até 25 & 2 & 6,0 \\
\hline & De 25 a 30 & 9 & 28,0 \\
\hline & De 30 a 40 & 13 & 41,0 \\
\hline & Mais de 40 & 8 & 25,0 \\
\hline
\end{tabular}


Sala de aula 28

Planejamento 28

Suas atribuições nesta Unidade de Ensino

Correção de atividades

Outras

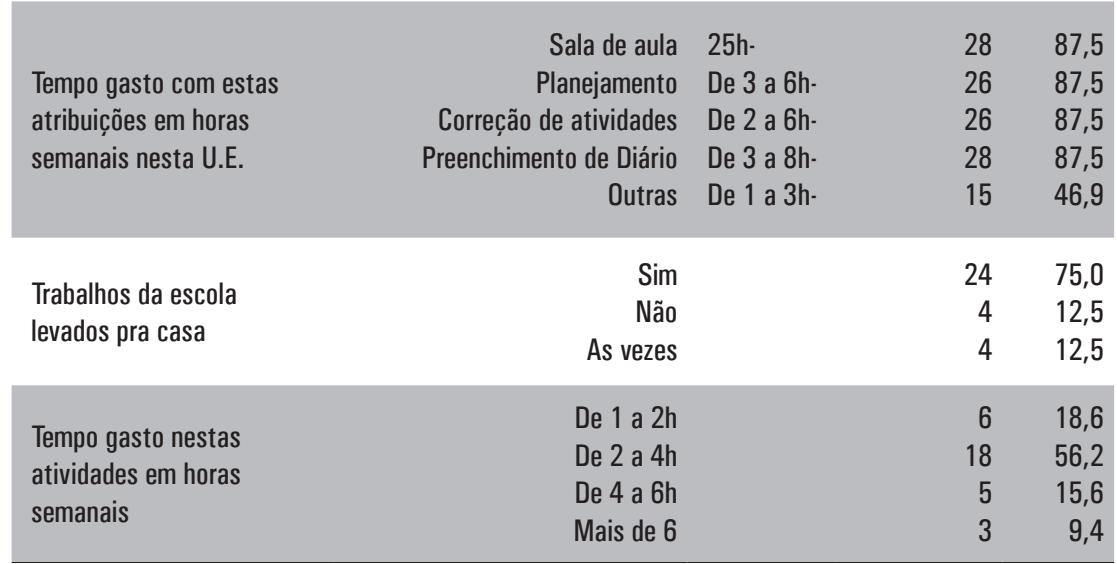

Fonte: dados da pesquisa.

Mesmo assim, buscando enriquecimento profissional, apenas $4 \%$ dessas professoras pagam com recursos próprios cursos para aprimorar e atualizar seu conhecimento, sua prática e seu currículo, como descrito na tabela 3. Porém, 21\% afirma participar de mais de duas formações continuadas oferecidas pelo município anualmente, separadas por anos, ciclos e direcionadas para cada segmento de ensino separadamente (TABELA 2).

Entre as professoras que afirmaram participar das formações oferecidas pela rede municipal, $75,0 \%$ concordaram que promovem grande impacto na prática pedagógica diária. Aprimorando, enriquecendo e alimentando a sede de saber inerente a profissão professor. Mesmo que, segundo elas, em algumas dessas formações os palestrantes deixem a desejar no sentido de suprir as expectativas criadas em razão do tema proposto em cada encontro (TABELA 2).

Algumas docentes afirmam que o tempo dedicado à formação representa um período de folga o qual consideram necessário para sair da rotina da sala de aula ainda que apenas uma vez por mês. Recebem essas formações como uma atividade diferente que, além de se afastar do ambiente de trabalho representam possibilidades de conhecer e trocar experiências entre colegas proporcionando comunhão entre a classe e ainda, o sentimento de que não estão totalmente sozinhas. 
Outro fator observado pelas professoras como causadores de desgaste e exaustão física e mental se refere a quantidade de atribuições que lhes são impostas pelo sistema além da prática em sala de aula. Segundo Cabral (2014) esse mal-estar, adoecimento e afastamento do professor primário é histórico, datam do início do século XX e são resultantes da implantação das reformas para reorganizar as escolas, proporcionando, devido às novas dinâmicas exigidas, tensões e conflitos. Neste sentido, Cardoso e Costa (2016) demonstraram em sua pesquisa que o excesso de atribuições, entre outros fatores, provoca esse desconforto.

É revelado na tabela 3 que 87,5\% das docentes têm de realizar planejamento, correção de atividades, preenchimento de diários além de $90,6 \%$ alegarem que se ocupam de outras atividades, descritas como xerocar, ensaiar músicas e apresentações artísticas, decorar salas e escolas para festividades, levar estudantes ao banheiro, às vezes até trocar-lhe a roupa.

Ozolio (2015) constata que um terço, 32,4\%, de professores na sua pesquisa relata esgotamento físico e mental no limite. Ressaltando que neste percentual reside a necessidade de políticas públicas direcionadas à prevenção e promoção de saúde desses profissionais. Não havendo tais ações o autor afirma que o estresse físico e mental pode desencadear, entre outras enfermidades, as síndromes, entre elas a de Burnout, a perda da energia vital, estudada há algumas décadas e considerada um dos principais problemas emocionais do professor (CODO, 1999; CODO et al., 2006).

Segundo $87,5 \%$ das professoras da nossa pesquisa, a média de horas empregadas com estas atribuições fora da sala de aula fica em torno de quatro e cinco horas semanais. Nesse contexto, 75,0\% afirmam que levam trabalho para casa todos os dias e 12,5\% levam às vezes, gastando em média mais 4 horas por semana em sua residência quando poderia estar com a família, amigos, em um lazer ou simplesmente descansando (TABELA 2).

\section{ANÁlISE DAS CARACTERISTICAS FÍSICAS DAS UNIDADES DE ENSINO E AS CONDIC̣̃̃ES DE TRABALHO}

Na tabela 3 vemos demonstrada a infraestrutura das Unidades de Ensino pesquisadas. Foi afirmado pelas protagonistas da pesquisa, que em 100,0\% delas existe uma sala e um banheiro privativo dos professores. Porém, em apenas $31,2 \%$, há um refeitório e uma quadra de esportes. As professoras afirmaram ainda que em $81,2 \%$ das escolas tem um auditório e em $46,9 \%$ delas existe uma sala específica para reuniões. 
TABELA 3. Características físicas da Unidade de Ensino e as condições de trabalho

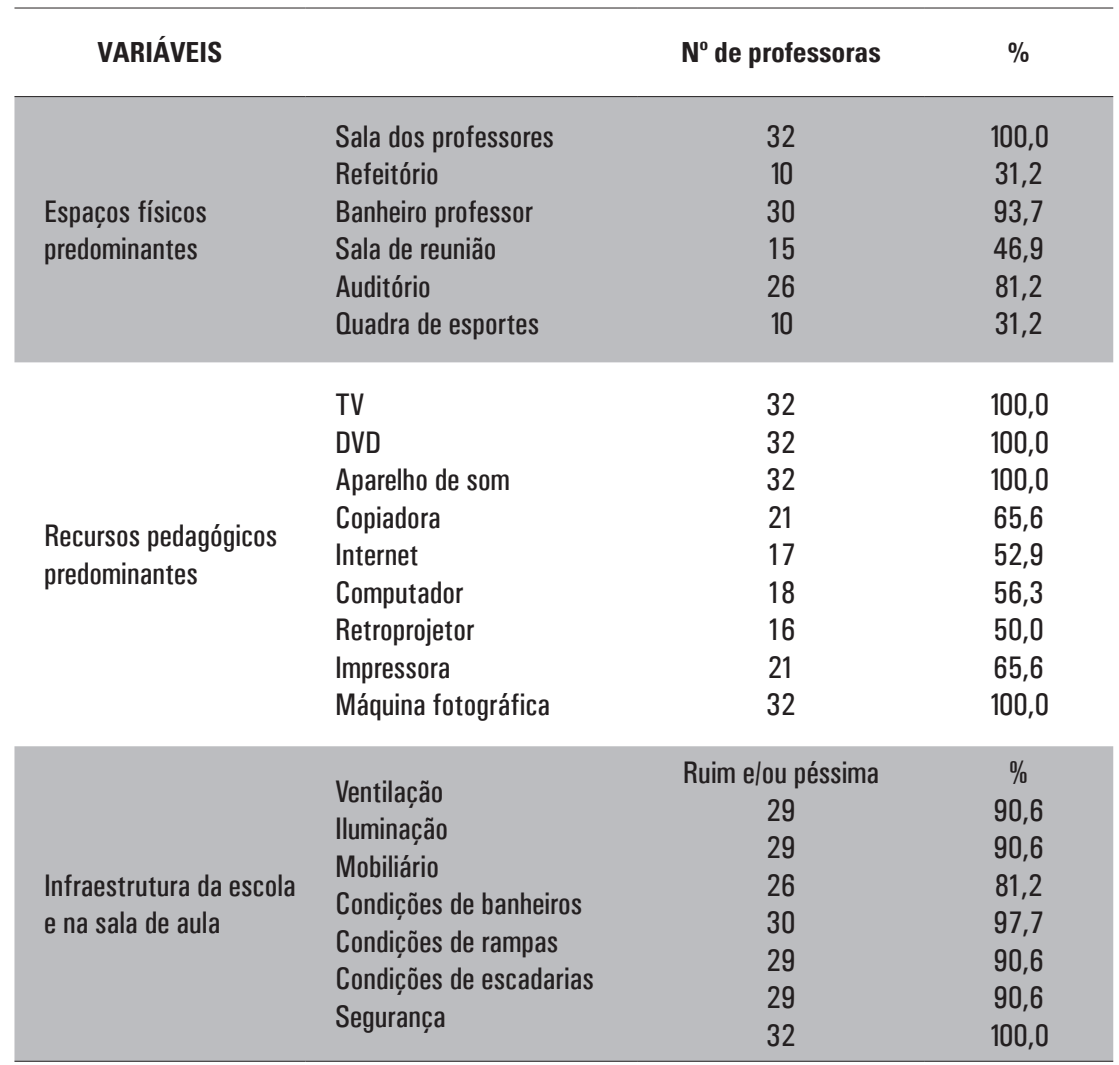

Fonte: dados da pesquisa.

Percebemos salas grandes nas escolas visitadas, porém para a quantidade de estudantes revelada na tabela 3, torna-se pequena e inviável para o trabalho pedagógico. Além de pouca ventilação e muito quentes, muitas delas com apenas um ventilador de parede para todos e afirmam que a iluminação é precária. Neste sentido, 90,6\% dos professores afirmam ser ruim ou péssima a ventilação e iluminação nas salas de aula. Em nosso clima tropical, o calor torna-se insuportável, provocando uma inquietação nos estudantes, querendo a todo o momento se retirar para beber água ou simplesmente receber um pouco de vento no pátio.

Pizzio e Klein (2015) destacam em seu estudo que a infraestrutura inadequada, entre outros fatores, é um predominante causador de adoecimento no professor. Neste sentido, Batista et al. (2010) cita o ambiente de trabalho como um dos contributos para o sofrimento profissional nas escolas. Em sua pesquisa detectou que a temperatura observada nas escolas ficou entre $26,7^{\circ} \mathrm{C}$ e $30,43 \mathrm{C}$. 
Quando o recomendado pela ABNT 17 sugere para ambientes interativos de cognição nos quais a atenção intelectual seja exigida, que a temperatura se limite entre $20^{\circ} \mathrm{C} \mathrm{e} 23^{\circ} \mathrm{C}$ (BATISTA et al., 2010).

Segundo as professoras, a estrutura física das escolas é definida como ruins e péssimas por $90,6 \%$ deles. Os docentes se referem a rampas em total desacordo com a lei de mobilidade, a escadarias íngremes e, ainda, em algumas dessas Unidades, existem reformas e/ou construções intermináveis, se estendendo às vezes, por anos sem conclusão. Persistindo no quesito condições físicas das Unidades de Ensino, $97,7 \%$ das protagonistas da pesquisa indicam que estão entre ruins e péssimas as condições dos banheiros, em alguns faltam água, limpeza, papel higiênico, sabonete e toalhas. E, ainda $81,2 \%$ dos questionados relatam mobiliários insuficientes, desconfortáveis, incômodos, velhos e mal distribuídos. No que se refere à segurança nas Unidades, 100,0\% declararam como ruim e péssima, pois, em alguns dias não contam com porteiros, vigilantes ou seguranças durante os turnos.

No que se refere à infraestrutura e aos recursos pedagógicos, as docentes informaram que em 100,0\% das escolas existe máquina fotográfica, TV, DVD e aparelho de som. Afirmaram também que dispõem de uma copiadora e uma impressora em 65,6\% e contam com um retroprojetor em 50,0\% delas (TABELA 3). Neste sentido, as professoras afirmaram que as práticas pedagógicas e a dinâmica do ensino na construção do conhecimento durante o processo de ensino e de aprendizagem se tornam bem mais interessantes, ricas e atraentes quando dispõem de mídias diversas.

Ao serem questionadas sobre a existência de computadores e internet, as professoras revelaram que em $56,3 \%$ e $52,9 \%$ respectivamente, possuem os instrumentos (TABELA 3). Assim, em alguns casos as atividades têm que ser realizadas em casa, com seus próprios computadores, internet e impressoras (TABELA 3). É grave e pertinente estas observações dos profissionais. Pois estes fatores estão inseridos no contexto das péssimas condições de trabalho a que são submetidos. Pereira (2014) afirma que a ausência de benefícios ao trabalhador se reflete em um dos multicausadores de adoecimento nestes ambientes.

Esta ausência ou carência de materiais e instrumentos necessários e indispensáveis na prática pedagógica diária é inconcebível no momento em que a aprendizagem e a tecnologia devem caminhar juntas e comungarem as transformações, mudanças e crescimentos inerentes ao ambiente proporcionando um desenvolvimento enriquecedor e atrativo, facilitando de todas as formas o processo de ensino e aprendizagem (REIS, 2014; SILVA, 2011; SILVA, 2014). 


\section{ANÁLISE DAS CONDIC̣̃̃ES FÍSICAS, PSICOLÓGICAS E SOCIAIS QUE INTERFEREM NA SAÚDE DOS PROFESSORES}

$\mathrm{Na}$ tabela 4 são retratados os principais sintomas e queixas causadoras de mal-estar, sofrimento e adoecimento relatados pelas professoras das primeiras letras quando demonstramos que 59,4\% relatam os sintomas de irritabilidade e estresse como constantes e recorrentes. Ocupando, portanto, os principais sintomas percebidos pelas professoras entre os citados, empatando com estado de tensão como o quarto mais sentido por elas.

A depressão foi relatada por $44,0 \%$ dessas profissionais, um fator causador de síndromes em se tratando de uma doença silenciosa. Porém, a insônia vem em segundo lugar com $75,0 \%$, o que nos reporta a associação do não dormir bem com o aparecimento do estresse e o aparecimento da tensão. Neste sentido, Ozolio (2015) afirma que $31,8 \%$ dos professores se sentem estressados e 34,4\% já admitem o esgotamento e a exaustão. Revelando durante a pesquisa que existe a necessidade de uma intervenção para promover a saúde destes profissionais, pois, fora verificado que o estresse não tratado poderá provocar síndromes que comprometem a prática docente.

Os fatores causadores de adoecimento predominantes nos artigos estudados durante a realização da nossa pesquisa foi o estresse em 25\% dos trabalhos e a Síndrome de Burnout em 22,2\% desses. Nesse contexto, Silva (2011) revela em sua investigação que condições de trabalho inadequadas, estruturas físicas das Unidades de Ensino e a grande quantidade de estudantes por sala, representam os principais causadores do estresse, assim como também de labirintite e depressão nos professores.

Acerca disso Costa, et al. (2013) afirmou que 11,2\% dos profissionais de sua pesquisa apresentaram Perfil 1 e 3\% Perfil 2 da Síndrome de Burnout. Demonstrando segundo os resultados, que essa prevalência deve ser levada em consideração. Pois, além da qualidade de saúde dos trabalhadores ficar comprometida, a educação não escapa da deteriorização. 
TABELA 4. Queixas e sintomas constantes e recorrentes das professoras

\begin{tabular}{|c|c|c|c|}
\hline VARIÁVEIS & & $\begin{array}{c}\mathbf{N}^{0} \text { de } \\
\text { professoras }\end{array}$ & $\%$ \\
\hline \multirow{10}{*}{ Queixas } & Cansaço & 30 & 93,8 \\
\hline & Dificuldade em levantar-se pela manhã & 28 & 87,5 \\
\hline & Noites mal dormidas & 19 & 59,4 \\
\hline & Ansiedade & 12 & 37,5 \\
\hline & Tristeza sem causa aparente & 4 & 12,5 \\
\hline & Choro com facilidade & 4 & 12,5 \\
\hline & Dificuldade em realizar atividades de rotina & 3 & 9,4 \\
\hline & Dificuldade em tomar decisões & 3 & 9,4 \\
\hline & Medos sem causas aparentes & 4 & 12,5 \\
\hline & Vontade de desistir da profissão & 4 & 12,5 \\
\hline \multirow{15}{*}{$\begin{array}{l}\text { Sintomas } \\
\text { percebidos }\end{array}$} & Insônia & 24 & 75,0 \\
\hline & Tensão & 19 & 59,4 \\
\hline & Preocupação & 12 & 37,5 \\
\hline & Irritação & 19 & 59,4 \\
\hline & Dor de garganta & 22 & 68,8 \\
\hline & Rouquidão & 28 & 87,5 \\
\hline & Perda da voz & 18 & 56,3 \\
\hline & Dor de cabeça & 17 & 52,9 \\
\hline & Dor no pescoço & 15 & 46,9 \\
\hline & Dor na coluna & 10 & 31,2 \\
\hline & Má digestão & 6 & 18,8 \\
\hline & Ansiedade & 7 & 21,9 \\
\hline & Depressão & 13 & 44,0 \\
\hline & Sentimento de incapacidade & 3 & 9,4 \\
\hline & Sentimento negativo em relação a você & 3 & 9,4 \\
\hline \multirow{4}{*}{$\begin{array}{l}\text { Já se afastou } \\
\text { da escola por } \\
\text { doença }\end{array}$} & $\operatorname{Sim}$ & 20 & 62,4 \\
\hline & Ed. Infantil & 3 & 9,4 \\
\hline & Anos iniciais do En. Fundamental & 17 & 53,9 \\
\hline & Não & 12 & 43,75 \\
\hline \multirow{8}{*}{$\begin{array}{l}\text { Qual o } \\
\text { diagnóstico }\end{array}$} & Afecção na garganta & 20 & 62,4 \\
\hline & Crise de ansiedade & 7 & 21,9 \\
\hline & Depressão & 6 & 18,8 \\
\hline & Perda da voz & 8 & 25,0 \\
\hline & Torcicolo & 15 & 46,9 \\
\hline & Tendinite & 9 & 28,2 \\
\hline & Dor na coluna & 10 & 31,2 \\
\hline & Síndrome de Burnout & 1 & 3,1 \\
\hline
\end{tabular}




\begin{tabular}{|c|c|c|c|}
\hline & & & 28,2 \\
\hline & De 15 a 30 dias & 9 & 21,9 \\
\hline & De 30 a 60 dias & 7 & 25,0 \\
\hline & De 60 a 90 dias & 8 & 12,5 \\
\hline Tempo de & Mais de 90 dias & 2 & 43,75 \\
\hline afastamento & Mais de uma vez & 12 & 9,4 \\
\hline da função por & Readaptado temporariamente & 3 & 9,4 \\
\hline doença & Ensino Fundamental & 3 & \\
\hline & Readaptado definitivamente & 8 & 25,0 \\
\hline & Ed. Infantil & 1 & $\angle 0,0$ \\
\hline & Ensino fundamental & 7 & \\
\hline Qual seu(s) & Tristeza & 20 & 62,4 \\
\hline sentimento(s) & Incapacidade & 12 & 43,75 \\
\hline se ou por estar & Ansiedade & 10 & 31,2 \\
\hline afastada & Preocupação & 20 & 62,4 \\
\hline & Conflitos com estudantes & 3 & 9,4 \\
\hline & Conflitos com os pais & 2 & 6,0 \\
\hline & Conflitos com a comunidade & 2 & 6,0 \\
\hline & Conflitos com a gestão & 9 & 28,0 \\
\hline Relaçoes socials & Falta de ajuda da gestão & 18 & 56,3 \\
\hline na comunidade & Sobrecarga de tarefas além da sala de aula & 28 & 87,5 \\
\hline & Os alunos demoram a se acalmar & 8 & 25,0 \\
\hline & Os estudantes interrompem a aula & 10 & 31,2 \\
\hline & Muito barulho externo & 9 & 28,0 \\
\hline & Conflitos com colegas & 2 & 6,0 \\
\hline
\end{tabular}

Fonte: dados da pesquisa.

Reportando-nos a literatura recente acerca da investigação do estresse em diversas instâncias, encontramos Weber et al. (2015) assegurando que há décadas atuam nos cursos de pós-graduação, participando e realizando pesquisas sobre o estresse ocupacional e as consequências na saúde do trabalhador. Neste sentido, Ozoilo (2015) mostra em sua pesquisa que $31,8 \%$ dos entrevistados apontam um elevado estado de estresse e $35,6 \%$, relatam ansiedade. Pois a rotina com salas de aulas superlotadas compromete o processo de ensino e de aprendizagem. Em um cenário no qual se percebe que os direitos sociais no Brasil estão sendo afetados diante da globalização do capital, a produção está desenvolvendo novas estruturas e dentre estas, a do currículo escolar. Produzindo nos docentes uma rebuscada no pensar da docência (GUARANY, 2012). Significando a inserção de novos elementos estranhos à rotina docente e esforços múltiplos para se adequar às novas exigências visando o cumprimento de metas determinadas. Podendo causar o adoecimento emocional que representa mais um fator causador de afastamento do profissional de suas atividades. 
Farber (1991 apud CARLOTTO, 2002, p. 24-25) considera o sentimento de cansaço e exaustão físico e emocional no professor como sintomas frequentes e constantes. O autor afirma que sentimentos de frustração emocional inerentes ao fenômeno de exaustão, podem ser causadores de sintomas psicossomáticos, entre eles, afecções gástricas. No nosso trabalho 18,8\% das nossas protagonistas revelaram estados de má digestão, o que podem afetar a garganta entre outros órgãos e 52,9\% das questionadas relatam sentirem dores de cabeça, entre muitos outros sintomas.

Segundo Farber (1991 apud CARLOTTO, 2002, p. 24-25) o profissional professor padece de forma recorrente de insônia, irritação, ansiedade, estados de raiva e tristeza, dentre outros sintomas e que podem ser acometidos de síndromes entre elas o burnout. Referindo-nos a nossa pesquisa, $12,5 \%$ das protagonistas afirmaram sentir tristeza e medos sem causa aparente, choro com facilidade e vontade de desistir da profissão.

A Síndrome de Burnout é considerada e identificada como sendo um determinado estresse ocupacional que acomete os profissionais de saúde e principalmente os de educação por se tratarem de ofícios que exigem envolvimento emocional, relação de cuidados e atenção direta, portanto exaustão emocional e física (HUBERMAN, 2000 in NÓVOA (org.), 2000; LEITER; MASLACH, 1988; MASLACH, 1993; MASLACH; JACKSON, 1981; 1986; MASLACH; LEITER, 1999, apud CARLOT'TO 2002, p.23; VANDERBERGHE; HUBERMAN, 1999;).

No entanto, os sintomas revelados pelo maior número de professoras, foi a rouquidão que ocupou o primeiro lugar com $87,5 \%$, dor de garganta em terceiro com $68,8 \%$ e perda da voz em quinto com $56,3 \%$. Neste sentido, Valente et al. (2015) define o aparelho fonador, ou seja, a voz como o primeiro e mais importante instrumento de trabalho do professor. Portanto, segundo o autor, tende a se desgastar tendo em vista a necessidade de uso constante e a falta de orientação acerca de cuidados preventivos que protejam as pregas vocais de afecções durante o exercício da docência, muitas delas irreversíveis, podendo levar o profissional ao afastamento da função. Valente et al. (2015) cita uma pesquisa de Roy (2004) referente a este desgaste do aparelho fonador, encontrado em $57,7 \%$ de professores entrevistados.

Ainda sobre os sintomas relatados pelas professoras expostos na tabela 4 , as dores no pescoço evidenciadas por $46,9 \%$ e na coluna citados por $31,2 \%$ demonstram um percentual significativo que merecem atenção. Segundo Camargo (2014) as LER/DORT (Lesões por Esforços Repetitivos/Distúrbios Osteomusculares Relacionados 
ao Trabalho), traumatismos dos membros, na coluna assim como os transtornos mentais e de humor como a ansiedade, se intercalam entre os problemas mais frequentes nos professores em todo o mundo.

Dessa forma o CID (Código Internacional de Doenças) $\mathrm{F}$, referente a distúrbios mentais e o CID M relacionado às LER/ DORT, são os que mais aparecem nos laudos das licenças médicas dos professores afastados de suas funções, temporária ou definitivamente readaptados (CAMARGO, 2014).

Camargo (2014) afirma que em alguns casos o CID F e o $\mathrm{M}$ aparecem juntos, como CID F/M, nos laudos. Impossibilitando precisar qual surgiu primeiro, ou mesmo a dificuldade de separálos. Neste contexto, Gouveia (2016) destaca em seu estudo que as enfermidades osteomusculares e os distúrbios da voz representam os mais predominantes causadores de adoecimento no professor.

Em se tratando dos sintomas percebidos em seu cotidiano é relatado em maior número de profissionais, $93,8 \%$, o constante cansaço seguido de perto por dificuldades de levantar pela manhã com $87,5 \%$, ainda, 59,4\% asseguram que são muitas as noites mal dormidas e 37,5\% revelam estados de ansiedade que vêm reforçar o primeiro. Essas referências reforçam o estado de exaustão física e emocional de que fala Plizzio e Klein (2015) quando evidenciaram que as causas do mal-estar docente surgem desde a precarização da educação e da profissão referente ao aspecto financeiro, ético e moral levando esses trabalhadores a um estado de estresse emocional e físico que pode levá-los aos transtornos de ansiedade e a depressão. E por vezes à Síndrome de Burnout.

Essa síndrome, de acordo com a literatura existente, é definida a partir da relação entre a intenção e a ação do trabalhador e as condições a que são submetidos e expostos a exercer sua prática (SLEEGERS, 1999, apud CARLOTTO, 2002, p. 26). O Burnout é encontrado em maior número e frequência em professores (MASLACH; LEITER, 1999, apud CARLOTTO, 2002, p. 23). Neste sentido Dalagasperina e Monteiro (2014) acreditam que o desconhecimento acerca da Síndrome de Burnout representa um fator negativo para a maior incidência e gravidade da síndrome nos profissionais.

Entre as 32 professoras da nossa pesquisa apenas uma (3,1\%), declarou ter sido diagnosticada com a Síndrome de Burnout. Porém, relata que só após cinco anos de tratamento de fobias diversas, de depressão, de ansiedade e de outras síndromes como a de pânico, é que fora detectada a Síndrome de Burnout. Afirma a docente que "a sensação é de que não existem mais forças, nem energias e nem sentido 
para nada. Chegou ao fundo do poço, literalmente. Revela que até tentou suicídio por sentir-se insignificante, inoperante e totalmente dispensável" (PROFESSORA). Reafirma que o tratamento com medicamentos e terapias ainda segue, porém necessitou se readaptar e tentar reaprender a viver.

Levy et al. (2009) afirma que apesar do burnout não ser uma doença, fatores definidos como graves e de risco, tal como o estresse físico, psicológico e social advindos da sua prática pedagógica, expõem os professores a doenças como ansiedade, depressão e consequentemente a síndromes, entre elas a de burnout.

Não há uma unanimidade em se tratando da relação entre o estresse ocupacional com a Síndrome de Burnout. No entanto, Maslach, Schaufeli e Leiter (2001, apud CARLOTTO 2002, p. 2) afirmam que todas as definições existentes na literatura, comungam que a exaustão emocional e mental, depressão, fadiga, estresse, entre outros sintomas mentais e comportamentais que se sobrepõem aos sintomas físicos, podem provocar ou levar ao burnout. Mesmo em pessoas que nunca apresentaram nem sofreram nenhum distúrbio patológico.

Diante desses fatos Costa et al. (2013) afirma que a estatística dos professores acometidos pela Síndrome de Burnout carece de atenção devido aos danos que provocam na saúde física, mental e social do profissional o que consequentemente provocará um efeito negativo na qualidade de ensino nas escolas. Neste sentido, Diehl e Marin (2016) em uma análise em 97 artigos acerca do tema, encontraram em 15 deles, focados na multidisciplinaridade, estudos que faziam uma relação entre o adoecimento mental e a Síndrome de Burnout e apontavam o estresse e a ansiedade como sintomas recorrentes que prevaleciam nos profissionais.

Ainda na tabela 4 é possível perceber que $62,4 \%$ das professoras da pesquisa responderam que já se afastaram das suas funções por doença. Entre os diagnósticos mais referidos estão afecções na garganta em $62,4 \%$, torcicolo com $46,9 \%$, dor na coluna em $31,2 \%$, tendinite com $28,2 \%$, distúrbios na voz afetaram $25,0 \%$, crise de ansiedade acometeu $21,9 \%$ e por fim depressão em 18,8\% delas. Estes números nos pareceram muito significativos. Compreendemos que existe um fenômeno de adoecimento evidente entre estes profissionais a partir das referências que fizeram e que estão reveladas aqui.

Neste contexto de adoecimento, a tabela 4 aponta que 43,75\% dos questionários da nossa pesquisa relatam haver se afastado da função docente por mais de uma vez no período de 2010 a 2015. Entre os docentes, a afirmação da quantidade de dias de afastamentos 
é significativa, pois, em média, nove professoras já se afastaram da escola por doença em torno de 46 dias em média. Um total $28 \%$ dos participantes da pesquisa já ficou longe das suas atividades entre 30 e 90 dias. Ainda neste relato, podemos afirmar que 25,0\% destes profissionais estão afastados definitivamente das atividades da sala de aula. Ou seja, são readaptados da função de professor e exercem outras atividades na escola.

Neste cenário de afastamento das atividades em sala de aula, tivemos uma representatividade significativa de professoras acometidas de sentimentos ao relatarem seu estado emocional neste contexto de impossibilidade de exercer sua função. O sentimento de preocupação e tristeza representou os mais referidos, com um percentual de $62,4 \%$ seguido de incapacidade com $43,75 \%$ e ansiedade com 31,2\% (TABELA 4).

Pareceu-nos importante ressaltar a necessidade de políticas públicas que atendam, tratem, previnam, acompanhem e cuidem desses profissionais, valorizando a profissão de uma forma ampla e irrestrita. Pois, a valorização dos profissionais depende principalmente de ações e políticas, voltadas à formação inicial e continuadas, salários, carreira e garantia de condições de trabalho, como definem as metas 15, 16, 17 e 18 do PNE (Plano Nacional de Educação, 2014).

Acreditamos que existe uma deteriorização anunciada na profissão e, portanto, na educação. Pois além dos relatos de sintomas, queixas e diagnósticos e, mais grave, o número de afastados por doenças, $87,5 \%$ das docentes afirmaram que sofrem com uma sobrecarga de atividades inclusive fora da sala de aula. Ainda relataram falta de ajuda da gestão escolar em um total de 56,3\%.

\section{PERCEPC̣ÃO E SENTIMENTOS SOBRE A PROFISSÃO}

Inseridos em um cenário de mal-estar e desconforto e reconhecendo a possibilidade de desencadear adoecimento e por consequência afastamento da função docente, ainda assim, temos um grupo de profissionais preocupados com o resultado do seu trabalho e empenhados em aprimorar e enriquecer seus conhecimentos através de formações oferecidas pela rede e fora dela, mesmo custeando com recursos próprios, desde que representem crescimento e desenvolvimento de novas práticas pedagógicas.

Conhecemos professoras que se empenham com a qualidade de ensino e em realizar sua prática da melhor maneira que sabem, mesmo diante das adversidades e exaustão produzida pelas condições 
de trabalho precárias. Neste sentido temos na tabela 5 um total de $84,0 \%$ de docentes que considera seu trabalho importante e prazeroso principalmente quando percebem o crescimento da construção do conhecimento em seus alunos.

Weber et al. (2015) demonstrou em seu trabalho que as relações sociais no ambiente escolar, entre estas, o desinteresse, indisciplina e falta de motivação dos estudantes e o baixo rendimento apresentado nas avaliações de desempenho, muitas vezes responsabilizando a ausência da família no processo educacional, influenciam a qualidade de vida dos professores representando assim, um entre os multifatores causadores de mal-estar, desconforto, sofrimento e adoecimento desse profissional.

TABELA 5. Sentimentos e percepções sobre si mesmo como professora e ser social.

\begin{tabular}{|c|c|c|c|}
\hline VARIÁVEIS & & $\mathbf{N}^{0}$ professores & $\%$ \\
\hline Visão da profissional & $\begin{array}{l}\text { Desgastante } \\
\text { Monótono } \\
\text { Prazeroso } \\
\text { Importante } \\
\text { Cansativo }\end{array}$ & $\begin{array}{c}11 \\
4 \\
28 \\
28 \\
18\end{array}$ & $\begin{array}{l}34,0 \\
12,0 \\
84,0 \\
84,0 \\
56,3\end{array}$ \\
\hline $\begin{array}{l}\text { Sentimentos } \\
\text { em relação ao } \\
\text { profissional }\end{array}$ & $\begin{array}{l}\text { Satisfeito } \\
\text { Muito satisfeito } \\
\text { Insatisfeito } \\
\text { Muito insatisfeito }\end{array}$ & $\begin{array}{c}22 \\
8 \\
2 \\
0\end{array}$ & $\begin{array}{c}32,4 \\
25,0 \\
6,0 \\
0,0\end{array}$ \\
\hline $\begin{array}{l}\text { Gostaria de ter } \\
\text { outra profissão? }\end{array}$ & $\begin{array}{l}\text { Sim } \\
\text { Não }\end{array}$ & $\begin{array}{l}12 \\
20\end{array}$ & $\begin{array}{l}37,5 \\
62,4\end{array}$ \\
\hline $\begin{array}{l}\text { Qual profissão } \\
\text { gostaria de ter? }\end{array}$ & $\begin{array}{l}\text { Psicóloga } \\
\text { Advogado } \\
\text { Enfermeira }\end{array}$ & $\begin{array}{l}8 \\
2 \\
2\end{array}$ & $\begin{array}{c}25,0 \\
6,0 \\
6,0\end{array}$ \\
\hline $\begin{array}{l}\text { Quanto tempo passa } \\
\text { com a família (em } \\
\text { hora/semana)? }\end{array}$ & $\begin{array}{l}\text { Até } 10 \\
\text { Até } 20 \\
\text { Mais de } 20\end{array}$ & $\begin{array}{c}23 \\
7 \\
2\end{array}$ & $\begin{array}{c}71,8 \\
21,9 \\
6,0\end{array}$ \\
\hline Qual o motivo? & $\begin{array}{l}\text { Falta de tempo } \\
\text { Falta de dinheiro } \\
\text { Cansaço } \\
\text { A distância }\end{array}$ & $\begin{array}{l}20 \\
19 \\
18 \\
4\end{array}$ & $\begin{array}{l}62,4 \\
59,2 \\
56,0 \\
12,0\end{array}$ \\
\hline
\end{tabular}




$\begin{array}{llll}\text { Há uma rotina } & & & \\ \text { de encontro } & \text { Sim } & 12 & 37,2 \\ \text { com amigos? } & \text { Não } & 20 & 62,4 \\ & & & \\ & \text { Falta de tempo } & 20 & 62,4 \\ \text { Qual o motivo? } & \text { Falta de dinheiro } & 19 & 59,2 \\ & \text { Cansaço } & 18 & 56,0 \\ & \text { A distância } & 4 & 12,0 \\ \text { Gostaria de passar } & \text { A família } & & \\ \text { mais tempo comigos } & \text { Com os dois } & & \\ & & 18 & 56,0 \\ & \text { Ler } & 14 & 43,2 \\ & \text { Ouvir música } & & 46,9 \\ \text { Oual seu lazer } & \text { Dançar } & 9 & \\ \text { preferido? } & \text { Cinema } & 7 & 28,0 \\ & \text { Praia } & 5 & 21,9 \\ & & 5 & 15,6 \\ & & 6 & 15,6 \\ \end{array}$

Fonte: dados da pesquisa.

Observamos profissionais totalizando $56,3 \%$ das questionadas, mesmo afirmando ser cansativa e $34,0 \%$, considerar desgastante a sua profissão, vibram e se emocionam alegrando-se em comemoração quando descobrem em sua turma, estudantes construindo de forma autônoma seu conhecimento e se desenvolvendo rumo a uma aprendizagem cognitiva e social. Enfim, quando seus alunos se desenvolvem e crescem a partir de uma prática educativa de qualidade e representativa, essas professoras mergulham em um sentimento de orgulho e satisfação, ainda que reconheçam e conheçam profundamente a existência de problemas (TABELA 5).

Estas professoras reconhecem os fatores causadores de malestar, de doenças físicas e psicológicas. Entendem e confessam que a falta de tempo e dinheiro para lazer, os raros encontros com familiares e amigos, provocam um estado de mal-estar e tristeza, levando-as às vezes a desenvolver um pensamento negativo acerca da profissão e até cogitam em desistir.

As faltas de políticas públicas e de investimentos fortes e significativos voltados para a educação deixam essas educadoras expostas à recorrente e crescente desvalorização social e econômica na qual, a burocracia que permeia a profissão, causa deteriorização em sua saúde física e mental (RODRIGUES, 2014). Mesmo diante de todos os percalços enfrentados em sua jornada, $25,0 \%$ do total pesquisadas 
se alimentam de um sentimento de satisfação em sua prática, com sua profissão. Ainda foi revelado por 32,4\% que se sentem satisfeitas em serem professoras e apenas $6,0 \%$ se declaram insatisfeitas na função.

\section{CONSIDERAÇÕES FINAIS}

Encontramos respostas positivas para nossas hipóteses acerca dos multicausadores do fenômeno do adoecimento das professoras das primeiras letras. Identificamos vários causadores elencados pelas docentes, como responsáveis pelo mal-estar físico, psicológico e social que as obrigam a afastarem-se da sala de aula. Entre estes aspectos provocadores de cansaço físico, psicológico e social, de acordo com as respostas, destacamos as estruturas precárias das UEs, a superlotação das salas de aula, a necessidade de deslocamentos entre redes e a extensa jornada de trabalho com atribuições que ultrapassam o ambiente escolar, como principais responsáveis pelas queixas ecoadas durante a investigação.

Levantamos uma nova hipótese, referida pelas docentes, como um amenizador do sofrimento, implementação de políticas públicas voltadas para o atendimento profissional do professor em seus diversos aspectos objetivando diminuir, tratar ou evitar o fenômeno do mal-estar docente nas primeiras letras. Pois a observação acerca de que o corpo, a mente e o ambiente de trabalho devem funcionar em um estado de harmonia para que seja possível diminuir os fatores causadores de mal-estar, desconforto e sofrimento na atividade ocupacional que em conjunto com a prática pedagógica prevalece sobre o trabalho docente, foi unânime.

Dessa forma, a necessidade de encontrar meios, através de políticas públicas determinantes visando qualidade de vida desta classe profissional, já está atrasada há muitas décadas. Afinal, atrelada a esta condição está a caminhada rumo à cultura de paz resultante do direito à educação de qualidade para todos, proposta pela UNESCO desde a sua criação em 1945, em seu primeiro parágrafo. Proposta que culminou com a união entre a UNESCO e a OIT, no ano de 1966, objetivando dimensionar a profissão professor de forma que proporcionasse um ensino de qualidade.

\section{REREFÊNCIAS}

ANDRADE, L. A. S.; CARDOSO, P. R. S. Mal-estar na educação: o sofrimento psíquico de professores em decorrência do trabalho. PERIÓDICOS. SE. EDU. BR-ARACAJUCiências Humanas e Sociais | Aracaju | v. 3 | n.2 | p. 51-64 | | periódicos.set.edu.br. 2016. 
AROUCA, S. S. A história natural das doenças. Saúde em Debate, n.1, p.15-19, out-dez, 1976. Disponível em: www.epsjv.fiocruz.br/dicionario/Dicionario2.pdf. Acesso em: 15 jul. 2015.

BAIÃO, L. P. M.; CUNHA, R. G. Doenças e/ou disfunções ocupacionais no meio docente: uma revisão de literatura -Revista Formação@Docente - Belo Horizonte - vol. 5, no 1, jan/jun2013. Disponível em: www.scielo.br/pdf/edreal/v40n4/2175-6236-edreal-51546. pdf. Acesso em: 15 jul. 2015.

BARATA, R. B. Epidemiologia e saber científico. Revista Brasileira de Epidemiologia, v.1, n.1, p. 14-27, 1998. Disponível em: www.scielo.br/pdf/edreal/v40n4/2175-6236edreal-51546.pdf. Acesso em: 15 jul. 2015.

BASTOS, J. A. Q. R. O Mal-Estar Docente, o Adoecimento e as Condições de Trabalho no Exercício do Magistério, no Ensino Fundamental de Betim/MG. UFMG. Belo Horizonte, 2009.

BATISTA, J. B. V., CARLOTTO, M. S., COUTINHO, A. S., AUGUSTO, L. G. S. (2010). Prevalência da Síndrome de Burnout e fatores sociodemográficos e laborais em professores de escolas municipais da cidade de João Pessoa, PB. Revista Brasileira de Epidemiologia, 13 (3), 502-512.

BORBA, B. M. R.; DIEHL, L.; SANTOS, A. S.; MONTEIRO, J. K.; MARIN, A. H. Síndrome de Burnout em professores: estudo comparativo entre o ensino público e privado. Psicol. Argum. doi 10.7213/ psicol. argum. 33.080. AO04, jan./abr., 2015 33(80), 270,281. Disponível em: <www2.pucpr.br>. Acesso em: dez. 2015.

BORGES DOS REIS, E. J. F.; ARAUJO, T. M.; CARVALHO, F. M.; BARBALHO, L. SLIVEIRA E SILVA, M. Docência e exaustão emocional. Educ. Soc., Campinas, v. 27, n. 27, p. 229-253, jan./abr. 2006. Disponível em http://www.cedes.unicamp.br. Acesso em: dez. 2016.

CABRAL, T. E. M. O Processo De Adoecimento Do Magistério Público Primário No Início Do Século XX: Indícios Do Mal-Estar Docente Nos Grupos Escolares Mineiros (1906-1930)- Viçosa, Minas Gerais - Brasil. 2014. 130f. Disponível em: www.poseducacao. ufv.br/wp-content/uploads/2016. Acesso em: 17 dez. 2016.

CAMARGO, D. A. A prevenção do adoecimento psíquico do trabalho. Rev. TST, Brasília, vol. 80, no 1, indb, 1568/5/2014. 157p. Disponível em: https://juslaboris.tst.jus.br/ handle/1939/61238. Acesso em: 17 dez. 2016.

CARDOSO, C. G. L. V.; COSTA, N. M. S. C. Fatores de satisfação e insatisfação profissional de docentes de nutrição. Ciência \& Saúde Coletiva, 21(8): 2357-2364 2016. Disponível em: www.scielo.br/pdf/edreal/v40n4/2175-6236-edreal-51546.pdf. Acesso em: 17 dez. 2016.

CARLOTTO, M. S. A Síndrome de Burnout e o trabalho docente. Revista Psicologia em Estudo 2002; Maringá; 7(1); p. 24-25.

CODO, W. (Coord.). Educação: carinho e trabalho - Burnout, a síndrome da desistência do educador que pode levar à falência da educação. $4^{\mathrm{a}}$ ed. Petrópolis, RJ: Vozes/Brasília: CNTE:UNB, Laboratório de Psicologia do Trabalho, 2006. 432 p.

CODO, W. (coord.); BATISTA, A. S.; GAZZOTTI, A. A.; VASQUES-MENEZES, I. Educação: Carinho e Trabalho. Burnout, a síndrome da desistência do educador, que pode levar à falência da educação. Petrópolis, RJ: Vozes. 1999 
CORDIÉ, A. Malestar em el docente: La educación confrontada com el psicoanálisis. Buenos Aires: Nueva Visión, p. 40-27. 2003.

COSTA, L. S., GIL-MONTE, P. R., POSSOBON, R. D. F., \& AMBrosAnO, G. M. Prevalência da Síndrome de Burnout em uma amostra de professores universitários brasileiros. Psicologia: Reflexão e Crítica. 26(4), 636-642, 2013. Disponível em: www.scielo. br. Acesso em: 15 jul. 2015.

DAlagasperina, P., \& MONTEIRO, J. K. Preditores da Síndrome de Burnout em docentes do ensino privado. Psico-USF, 19(2), 263-275. 2014.

DEJOURS, C. Da psicopatologia à psicodinâmica do trabalho. In: LANCMAN, S.; SZNELMAN, L. I. (org.). Rio de Janeiro: Editora Fiocruz/Brasilia: Paralelo 15, 2004. 346p.

DIEHL, D.; MARIN, A. H. Adoecimento mental em professores brasileiros: revisão sistemática da literatura. Universidade do Vale do Rio dos Sinos - Estudos Interdisciplinares em Psicologia, Londrina, PR, v. 7, n. 2, p. 64-85, dez. 2016. Disponível em: http:/ /www.uel. br. Acesso em: 10 jan. 2017.

ESTEVE ZARAGOZA, J. M. Profesores en conflicto. Madrid: Narcea, 1984.

ESTEVE ZARAGOZA, J. M. El malestar docente. $3^{\text {a }}$ ed. Barcelona: Ediciones Paidós, 1987-1994.

ESTEVE ZARAGOZA, J. M. Os professores perante a mudança social: o mal-estar docente. In: Nóvoa (org.) Profissão Professor. 22ª ed. Porto, p. 97- 98, 1995.

ESTEVE ZARAGOZA, J. M. O mal-estar docente: A sala de aula e a saúde dos professores. São Paulo: Tradução: Durley de Carvalho Cavicchia. $3^{\text {a }}$ ed., Bauru: Edusc, 1999. 175p. (apud CARLOTO, 2002, p. 23).

FARBER, B. A. Crisis in education. Stress and burnout in the American teacher. São Francisco: Jossey - Bass 1991. (apud CARLOTTO, 2002, p. 24, 25, 26, 27).

FREUD, S. (1924). Edição standard brasileira das obras psicológicas completas de Sigmund Freud. Rio de Janeiro: Imago; v. XI (1969), p. 125-36. V. XIX (1924), P. 189199. V. XXI (1930), V XXIII (1937-1939), 2004. Disponível em: <https://psicologado.com> Abordagens > Psicanálise (C) Psicologado.com.br>. Acesso em: 20 dez. 2014.

GATTO, M. E. Desgaste psíquico em el equipo de salud. Síndrome de Burnout. Pren Méd Argent; 87: 357-61. 2000. Disponível em: www.scielo.br/scielo.php. Acesso em: 05 jul. 2016.

Gil, A. C. Como Elaborar Projetos de Pesquisa. $5^{a}$ ed. São Paulo: Atlas, 2010, p. 27).

GOUVEIA, L. A. V. N. As condições de trabalho e o adoecimento de professores na agenda de uma entidade sindical. Saúde Debate | Rio de Janeiro, v. 40, n. 111, p. 206-219, OUTDEZ 2016. Disponível em: www.scielo.br/scielo.php. Acesso em: 05 fev. 2017.

GUARANY, A. M. B. Trabalho Docente, Carreira Doente: a privatização, a lógica produtivista e a mercantilização na e da educação e seus efeitos sobre os docentes. Revista Educação por Escrito - PUCRS, v.3, n.1, jul. 2012. 
HUBERMAN, M. O ciclo de vida profissional dos professores. In: NÓVOA, A. (org.). Vidas de professores. $2^{a}$ ed. Porto: Porto, p. 31-61, 2000.

HARNIK, S. Todos pela Educação - De Olho nas Metas. 2011. Disponível em http:/ / www.todospelaeducacao.org.br. Acesso em: 10 dez. 2016.

KOGA, G. K. C.; MELANDA, F. N.; SANTOS, H. G. dos; SANT'ANNA, F. L.; GONZALEZ, A. D.; MESAS, A. E.; ANDRADE, S. M. de. Fatores associados a piores níveis na escala de Burnout em professores da educação básica. Cad. Saúde Colet., Rio de Janeiro [online]. vol. 23, n. 3, pp. 268-275268. ISSN 1414-462X. 2015. Disponível em: http://dx.doi.org/10.1590/1414-462X201500030121. Acesso em: 05 jul. 2016.

LEITER, M. P.; MASLACH, C. The impacto $\mathrm{f}$ interperonal environment on burnout and organizational cmmitment. Journal of Organizational Behavior, 9, 297-308. 1988. (apud CARLOTTO 2002). Disponível em: www.scielo.br/scielo.php. Acesso em: 05 jul. 2016.

LEONARDO, N. S. T.; SUZUKI, M. A. Medicalização dos problemas de comportamento na escola: perspectivas de professores. Fractal, Rev. Psicol., v. 28 - n. 1, p. 46-54, 2016. Disponível em: www.scielo.br/scielo.php. Acesso em: 10 dez. 2016.

LEVY, G. C. T. M.; NUNES SOBRINHO, F. P.; SOUZA, C. A. A. Síndrome de Burnout em professores da rede pública. Produção, v. 19, n. 3, p. 458-465, 2009. Disponível em: www. scielo.br/pdf/prod/v19n3/04.pdf. Acesso em: 10 dez. 2016.

LIRA, A.; MEDEIROS, J. N. F. Adoecimento e colapso do professor: impactos da violência na escola. EDUCERE - Investigación Arbitrada - ISSN: 1316-4910 - Año 19 -n. 64, 2015/765-775. Brasília-DF. Brasil, 2015. Disponível em: www.scielo.br/scielo.php. Acesso em: 10 dez. 2016.

MACMAHON, B.; PUGH, T.; IPSEN, J. Métodos de Epidemiologia. México: La Prensa Medica Mexicana, 1965.

MASLACH, C. Burnout: A multidimensional perspective. In: SCHAUFELI, W. B., MASLACH, C., MAREK, T.(Eds.), Professional burnout: Recent developments in theory and research, (p. 19-32). Washington, DC: Taylor \& Francis, 1993 (apud CARLOT'TO E CÂMARA, 2006, p.168). Disponível em: www.scielo.br/scielo.php. Acesso em: 15 jul.2015.

MASLACH; C.; JACKSON, S. E. (1981). The measurement of experienced burnout. Journal of Occupational Behavior, 2, 99-113. 1981 (apud CARLOTTO 2002, p. 498). Disponível em: www.scielo.br/scielo.php. Acesso em: 10 dez. 2016.; 1986.

MASLACH, C.; LEITER, M. P. Trabalho: Fonte de prazer ou desgaste? Guia para vencer o estresse na empresa. Tradução: Mônica Saddy Martins. Campinas, SP: Papirus, 1999 (apud CARLOTTO 2002, p. 23). Disponível em: www.scielo.br/scielo.php. Acesso em: 10 dez. 2016.

MASLACH, C., SCHAUFELI, W. B., \& LEITER, M. P. Job burnout. Annual Review Psychology, 52, 397-422. 2001 (apud CARLOTTO; CÂMARA, 2006, p. 168, 169). Disponível em: www.scielo.br/scielo.php. Acesso em: 10 dez. 2016.

MINAYO, M. C. S. O desafio do conhecimento. 11ª ed. São Paulo: Hucitec, 2008

MINAYO, M. C. S. (org.). Pesquisa social: teoria, método e criatividade. Petrópolis: Vozes, 2001. 
OLIVEIRA, W. C.; SILVA, F. G. Alienação, Sofrimento E Adoecimento Do Professor Na Educação Básica. (UFVJM), Vales do Jequitinhonha e Mucuri, 2015. Disponível em: www.scielo.br/scielo.php. Acesso em: 10 dez. 2016.

OZOLIO, L. F. A. Adoecimento Funcional Docente Na Rede Municipal De Educação De Belo Horizonte: Estudo De Caso Da Regional Pampulha. UFJF. 2015.

PENNA, M. L. F. Reflexões sobre a epidemiologia atual. In: BAGRICHEVSKY, M.; PALMA, A.; ESTEVÃO, A.; DA ROS, M. (org). A Saúde em Debate na Educação Física, v.2. Blumenau: Nova Letra, 2006.

PIZZIO, A.; KLEIN, K. Qualidade de vida no trabalho e adoecimento no cotidiano de docentes do ensino superior. Educ. Soc., Campinas, v. 36, n. 131, p. 493-513, abr.-jun., 2015. Disponível em: www.scielo.br/scielo.php. Acesso em: 10 jul. 2016.

REIS. M. I. A. O adoecimento dos trabalhadores docentes na rede pública de ensino de Belém-Pará. Doutorado em Educação. UFPA, Belém, 2014 216p. Disponível em: www. scielo.br/scielo.php. Acesso em: 15 jul. 2015.

REIS. M. I. A.; MAUÉS, O. C.. Educação, trabalho e saúde docente - desafios para a qualidade de ensino, Pesquisa realizada com professores dos municípios do Oeste do Pará. UFPA/CNTE, 2007. Disponível em: www.anpae.org.br/congressos_antigos/ simposio2007/301.pdf. Acesso em: 10 dez. 2016.

RODRIGUES. S. C. Ser Professor Em Tempos De Crise De Identidade E Mal-Estar Docente: As Autorrepresentações De Professores De Uma Escola Pública De Garanhuns, PE - Brasil. Lisboa, 2014.

SILVA, F. G. Professor e a educação: entre o prazer, o sofrimento e o adoecimento. Revista Espaço Acadêmico, n. 124, 2011. Disponível em: www.scielo.br/scielo.php. Acesso em: 15 jul.2015.

SILVA, R. A. O.; GUILLO, L. A. Trabalho docente e saúde: um estudo com professores da educação básica do sudoeste goiano. Revista eletrônica do programa de pós-graduação em educação. v. 11. n. 2. 2015. Disponível em: www.scielo.br/scielo.php. Acesso em: 15 set. 2015.

SLEEGERS, P. Professional identity, school reform, and burnout: some reflections on teacher burnout. In: VANDERBERGUE, R. \& Huberman, M. A. (ed.), Understanding and preventing teacher burnout: a source book of international practice and research (p.247-255). Cambridge: Cambridge University Press. 1999. (apud CARLOTTO, 2002, p. 26). Disponível em: www.scielo.br/scielo.php. Acesso em: 15 jul. 2015.

SOUZA, M. C. C. C. de. A psicanálise e a depressão de professores. Notas sobre a psicanálise e a história da profissão docente. Em L. de Lajonquière \& M. C. M. Kupfer (org.). Psicanálise infância e educação (p.107-115). LEPSI São Paulo. 2002. Disponível em: www.scielo.br/ scielo.php. Acesso em: 15 jul. 2015.

VALE, P. C. S.; AGUILLERA, F. Revisão de literatura estresse dos professores de ensino fundamental em escolas públicas •Uma Revisão De Literatura. São Paulo, 2016. DOI: 2317- 3394, rpds.v5i1.712. Disponível em: www.scielo.br/scielo.php. Acesso em: 15 jan. 2016. 
VALENTE, A. M. S. L.; BOTELHO, C.; SILVA, A. M. C. Distúrbio de voz e fatores associados em professores da rede pública. Rev. bras. Saúde ocup., 40 (132): 183-195, São Paulo, 2015. Disponível em: www.scielo.br/scielo.php. Acesso em: 19 jul. 2016.

VANDENBERGHE, R.; HUBERMAN, A. M. Understanding and preventing teacher burnout: a source book of international practice and research. Cambridge: Cambridge University Pres. S. 1999. 362 p. (apud CARLOTTO, 2002).

VERGARA, S. C. Métodos de pesquisa em administração. São Paulo: Atlas, p. 47, 2005.

WEBER, L. N. D.; LEITE, C. R.; STASIAK, G. R.; SANTOS, C. A. da S.; FORTESKI, R. O Estresse no trabalho do professor. Imagens da Educação, v. 5, n. 3, p. 40-52, 2015. Disponível em: www.scielo.br/scielo.php. Acesso em: 19 jul. 2016.

Submetido: $19 / 11 / 2017$

Aprovado: 28/08/2018

Contato:

Edna Maria Rodrigues de Souza Rua Umburanas, 40/202, Bongi

Recife $\mid$ PE $\mid$ Brasil

CEP 50.751-440 